Р.В.Множинська,

кандидат філософських наук,

доцент кафедри філософії

і релігієзнавства КНУТД

\title{
КАЛЛІМАХ І ГРИГОРІЙ САНОЦЬКИЙ (До питання про українсько-італійські філософські зв'язки в XV ст.)
}

Відродження, або Ренесанс, $\square$ це та епоха в історії культури Європи, що прийшла на зміну Середнім вікам і передувала Просвітництву. В Iталії вона припадає на початок XIV (а в Свропі на XV-XVI ст.). Характерна їі риса - світський характер культури, ії гуманізм і антропоцентризм (тобто інтерес, передусім, до людини і іiі діяльності). В цей час посилюється увага до античної культури, яка немовби відроджується. У Кареджі, поблизу Флоренції, виникла так

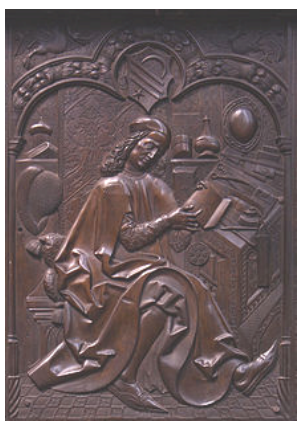
звана Платонівська академія у (1459-1521), засновником і очільником якої був Марсіліо Фічино. До неї входив, зокрема, відомий італійський гуманіст Філіппо Буонаккорсі Каллімах (Philippus Callimachus Experiens; 1437-1496) - поет і прозаїк, писав латинською мовою. Спочатку діяв і творив у Венеції, а десь в 1462-1468 рр. перебував у Римі, де займав посаду секретаря кардинала Бартоломео Ровеллі. Будучи у складі так званої Платонівської Академії, прибрав грецьке прізвисько Каллімах. Підтримував стосунки з відомими гуманістами Марсіліо Фічино, Піко делла Мірандола і Лоренцо Медічі.

Тікаючи від переслідувань папи римського, з'явився 1470 року у Польщі. Папа вимагав видачі Каллімаха, i сейм у Пьотркові погодився на це. Але проти виступив Львівський архієпископ Григорій Саноцький, який забрав італійського мислителя до себе у Львів, де Каллімах жив у його заміському домі. Навколо цих непересічних постатей гуртувалися учні й друзі, котрі невдовзі організували літературно-наукове товариство, зразком для якого була гуманістична Римська Платонівська Академія Помпонія Лето, Платіни і Каллімаха. Осідком товариства став маєток Григорія у містечку Дунаїв, для якого виклопотав 1470 року привілей на ярмарки і торги $і$ яке 
укріпив так, що 1474-го року вчинив у ньому опір татарам.

Каллімах дуже високо цінував розум і знання Григорія Саноцького. Щойно зазнайомившись із ним, італійський гуманіст був дуже здивований, що зустрів на півночі людину, яка так глибоко обізнана 3 філософією і дотримується передових поглядів. «3 вуст того великого чоловіка, - писав Каллімах, - плинуть міркування незмірно поважні і такі, що переважають наш розум...» Італійський гуманіст зображує Григорія як взірець пастиря, а в іншому місці каже, що зрідка до самого Львова заїжджав, бо мерщій поспішав до улюбленого Дунаєва, що Григорій всю архієпископію віддав до управління власникам, ніколи від них звіту не вимагаючи. Помер Каллімах у віці 59 років від морової пошесті, а його тіло урочисто поховано в домініканському костелі в Кракові. Залишив по собі багато поетичних і прозових латиномовних творів, зокрема й трактат «Життя і звичаї Григорія з Санока».

Григорій Саноцький (Gregorius Sanoceus/ Grzegorzz Sanoka;

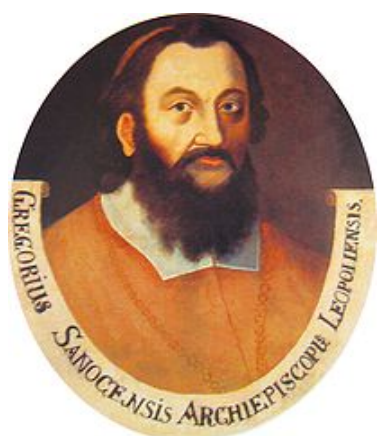
бл. 1406-1477) - архієпископ львівський протягом 1451-1477 рр., професор Краківської академії, ренесансний гуманіст, критик схоластики і поет. Засновник першого гуманістичного гуртка в Україні, куди входив і Філіппо Буонаккорсі Каллімах.

У 1433 р. Григорій Саноцький став професором римської поезії. Протягом 1433-1437 рр. був вихователем синів краківського воєводи Івана Тарновського, а пізніше - синів короля Польщі Казиміра Ягелончика. Напередодні 1437 р. прийняв священицький сан і виїхав на подальші студії до Італії, де перебував три роки. У канцелярії папи Свгенія IV виконував обов'язки музиканта і копіювальника. Після повернення до Кракова одержав 1439 р. ступінь магістра мистецтв i почав викладати в Краківській Академії класичну поезію. Згодом жив у повітовому місті Величка малопольського воєводства і виконував обов'язки приходського священика, маючи тісний контакт 3 краківським науковим середовищем. 1440 р., обійнявши посаду парафіяльного священика, заснував лікарню для убогих у місті Бжеску. Протягом 1440-1450 рр. перебував в Угорщині, де певний час виховував синів семиградського воєводи Яна Хун'яді. Жив при дворі хорватського гуманіста архієпископа Яна Вітеза (Jan Vitéz; 1405-1472). 
Як капелан польського короля Владислава III Варненчика і нотаріус королівської канцелярії, Григорій Саноцький взяв участь в угорській (1440р.) і варненській (1444р.) воєнних експедиціях. Відомо також, що за намовою руського воєводи Анджея Одровонжа погодився на приведення до Львова бернардинів (католицького «Ордену Братів Менших») [6, 67]. Згодом про життя Григорія Саноцького писав письменник, історик і громадський діяч Юзеф Гнат Крашевський (Józef Ignacy Kraszewski; 1812-1887) у книжці під назвою «Стремінчик» (Strzemieńczyk). Помер Григорій раптово в Рогатині 1477 або 1479 р. [Див. 6, 348]. Про його смерть польський історик Ян Длугош писав: «Не відомо, чи помер натуральною смертю, чи внаслідок отруєння: «Mor bone, in certum est, extinctu san veneno afoe minis propinato, inquasintempe ratese age bat» (Не відомо, чи від хвороби помер, чи від отрути, підсипаної жінками, до яких мав непомірний потяг) [2, XIII, p. 553; 3, Str.561].

Талант Григорія Саноцького, як і всіх ренесансних гуманістів, був непересічним і багатогранним. Але він виявився, сформувався і розвинувся не без впливу навколишнього середовища, кола визначних особистостей панєвропейського масштабу. 3 ким спілкувався Григорій Саноцький під час п'ятирічного перебування в Німеччині, нам, на жаль, невідомо. Але, мешкаючи у Львові, мислитель підтримував зв'язки з відомим польським діячем, істориком і дипломатом Яном Длугошем (Лонгус) та лікарем і астрологом Мартином із Перемишля. Обидва дуже його хвалили. Потому, коли подався до Кракова і став учителем латині синів короля Казиміра Ягелончика (1447-1492), брав участь також у кількох дипломатичних місіях до римського папи Сикста IV, Інокентія VIII і до Константинополя. У краківському середовищі Григорій мав зв'язки 3 німецьким гуманістом і педагогом Конрадом Целтісом (1459-1508) та з утвореним ним «Надвіслянським літературним товариством» (Sodalitas Litteraria Vistulana). Як близький приятель дворецького королівських синів Станіслава Шидловецького, мав великий вплив на східну політику королів Ягелончика і Олбрахта, які довіряли йому дипломатичні місії. Це сприяло новим знайомствам і плідним контактам. Відомо, зокрема, що, працюючи в Угорщині учителем дітей угорського військового і політичного діяча, воєводи Трансильванії, генерала й регента угорського королівства Яна Хуньяді (1387-1456), Григорій відвідував гурток гуманістів, де спізнався, зокрема, 3 італійським гуманістом Павлом Вергеріо і Філіппом Подахатером 
3 острова Кіпр [3, VI, Str. 560].

Але найбільше нам відомо про плідне спілкування Григорія Саноцького з Філіппом Буонакорсі Каллімахом. Коли, тікаючи від переслідувань папи римського, останній з'явився 1470 р. в Польщі і папа вимагав його видати, а сейм у Пьотркові погодився на це, Саноцький виступив проти і запросив італійського мислителя до Львова, де Каллімах почав жити в його домі. Як ми вже зазначали, навколо цих непересічних постатей гуртувалися учні й друзі, які невдовзі організували літературно-наукове товариство, зразком для якого була гуманістична Академія Римська Помпонія Лето, Платіни і Каллімаха. Осідком товариства став маєток Григорія у містечку Дунаїв, для якого виклопотав 1470 р. привілей на ярмарки і торги і яке укріпив так, що 1474 р. зміг вчинити в ньому опір татарам (2, XIII, p. 515).

Каллімах дуже високо цінував розум і знання Григорія Саноцького. Щойно познайомившись із ним, італійський гуманіст був дуже здивований, що зустрів на півночі людину, яка так глибоко обізнана з філософією і дотримується передових поглядів. «3 вуст того великого чоловіка, - писав Каллімах, - плинуть міркування незмірно поважні й такі, що переважають наш розум...» (Див. 5, Str. 65; а тж. 10; 11). Італійський гуманіст вважає Григорія взірцем пастиря, а в іншому місці визнає, що до Львова заїжджав зрідка, бо мерщій поспішав до улюбленого Дунаєва, що Григорій всю архієпископію віддав до управління власникам, ніколи від них звіту не вимагаючи [3, VI, Str. 558]. Каллімах помер у віці 59 років від морової пошесті, а його тіло урочисто поховано в домініканському костелі в Кракові. Залишив по собі поетичні і прозові латиномовні твори, зокрема «Життя кардинала Збігнєва Олесніцького», «Життя і звичаї Григорія з Санока» i «Три книги про короля Владислава» про польського короля Владислава Варненчика (1414-1444), який загинув у битві з турками біля болгарського міста Варна.

Що ж до суто філософських проблем, то свого ставлення до них Каллімах не висловлював. Незважаючи на це, польські історики літератури висловлювалися про нього як про «правдивого філософа, людину таланту надзвичайного», єдину світлу постать серед суцільної темноти, в яку схоластична філософія занурила XV століття. Проте подибуємо і критичне оцінювання його спадщини, як здається, не вельми вмотивоване: «Філософом ніяким Григорій не був: бо не мав ані системи, ані жодного твору філософського змісту не залишив, а навіть ніколи того робити не збирався»; «антична 
філософія була йому невідома, хіба що, настільки, наскільки про неї $з$ творів Цицерона вичитав, бо грецької не знав» (Див. 5, III, S. $237,238,254)$. Ідучи за цією логікою звинувачення, подібне можна закинути більшості ранніх ренесансних гуманістів панєвропейського масштабу, які так само були, передусім, вільнодумними гуманістами, котрі проголошували memento vi vere.

Григорій Саноцький першим серед вітчизняних мислителів рішуче й відверто критикував схоластичну філософію, яку називав «сонним маренням наяву», та вважав себе послідовником філософії Епікура - «доброго християнина і високоморальної людини». Ця думка була на той час дуже сміливою, бо у середньовічній літературі епікуреїзм тлумачили як радикальний натуралізм, або гедонізм. Тому побутувало негативне ставлення до Епікура, а його прихильників називали «поросятами із череди Епікура» (Porci de grege Epicuri). Григорій визнавав за епікуреїзмом право на існування поряд з іншими філософськими вченнями, бо Епікур, на його думку, «займався тілом - матеріальним світом, а інші вчені займаються душею - світом духовним» $[1,104]$.

Мислитель виступав за розмежування світської і церковної влади, відокремлення церкви від держави та за їх невтручання у справи одна одної. Він закликав до відокремлення, унезалежнення природознавства від релігії, до наукового пояснення явищ природи; критикував тих, які намагаються закони природи підпорядкувати теології. Насамкінець, заради об'єктивності, зауважимо, що крім перелічених нами свідчень, так би мовити, позитивного характеру, $\epsilon$ і скептичні.

В цілому ж важко заперечити все попередньо сказане, а також усталену вже думку польських і українських науковців про те, що Саноцький був першим серед вітчизняних мислителів, хто рішуче й відверто критикував схоластичну філософію, яку називав «сонним маренням наяву» і започаткував новий ренесансно-гуманістичний етап у філософії України та Польщі. Вихідною позицією його філософії було характерне для гуманістів заперечення авторитетів i прагнення до самостійного мислення та критичного осмислення текстів античних філософів [1, 130]. Продовжували гуманістичну культуру в Україні такі поети, письменники, теологи і вчені: Юрій Дрогобич (Котермак) (бл. 1450-1494), Павло Кросненський (Русин iз Кросна) (бл. 1470-1517), Лукаш із Нового Міста (пом. бл. 1542), Станіслав Оріховський-Роксолан (1513-1566). 


\section{ЛІТЕРАТУРА}

1. Литвинов В.Д. Ренесансний гуманізм в Україні. - К., 2000.

2. Dlugosz Jan. Historiae polonicae. - XII, 1878.

3. Encyklopedia kościelna. - VI, 2014.

4. Wiszniewski Michat. Historia literatury polskiej (tom 1-10, 1840-1857).

5. Nowicki A. Grzegorz z Sanoka i Filip Kallimach // Z dziejów polskiej myśli

filozoficznej i społecznej. - Warszawa, 1956. - T.I.

6. Nowicki A. Filozofia włoskiego odrodzenia. - Warszawa, 1967.

Множсинська Р.В. Каллімах і Григорій Саноџький. (До питання про украӥнсько-італійські філософські зв'язки в $X V$ ст.).

У статті на основі фактичного матеріалу висвітлюються зв'язки відомого італійського гуманіста Філіппо Буонаккорсі Каллімаха (Philippus Callimachus Experiens; 1437-1496), який входив до складу так званої Платонівської Академії в Римі, з Григорієм Саноцьким (1406-1477) - архієпископом львівським, професором Краківської академії, ренесансним гуманістом, критиком схоластики і поетом. Саноцький був засновником першого гуманістичного гуртка в Україні, куди входив і Каллімах, який після втечі з Італії жив у домі Львівського архієпископа. Він залишив спогади про спілкування з Григорієм Саноцьким.

Множинская Р.В. Каллимах и Григорий Саноикий. (К вопросу украинско-итальянских философских связей в XV вв.).

В статье на основе фактического материала освещаются связи известного итальянского гуманиста Филиппо Буонаккорси Каллимаха (Philippus Callimachus Experiens; 1437-1496), который входил в состав так называемой Платоновской Академии в Риме, с Григорием Саноцким (1406-1477) архиепископом львовским, профессором Краковской академии, ренессансным гуманістом, критиком схоластики и поэтом. Саноцкий был основателем первого гуманистического кружка в Украине, куда входил и Каллимах. Он оставил воспоминания об общении с Григорием Саноцким.

Mrozinska R.V. Callimachus and Gregory of Sanok (Ukrainian-Italian Philosovskih relations in the FIFTEENTH century.).

In this article on the basis of actual material discusses the relationship between the famous Italian humanist Filippo Buonaccorsi Callimachi (Philippus Callimachus Experiens; (1437-1496) was part of the so-called Platonic Academy in Rome, with Gregory Sanocki (1406-1477) - Archbishop of Lviv of the Professor of the Krakow Academy, Renaissance humanist, the critic of scholasticism and the poet. Sanocki was the founder of the first humanistic group in Ukraine, which included Callimachus, who after fleeing from Italy, lived in the house of the Archbishop of Lviv. He left memories dealing with Gregory Sanocki, which are listed at the end of the article in Latin. 